\title{
The Use of the Decisions of the European Court of Human Rights, the Constitutional Court of the Russian Federation when Investigating the Problems of the Criminal Law of the Russian Federation (Article One)
}

\author{
Valentina I. Plohova* \\ Novosibirsk State University \\ 2 Pirogova Str., Novosibirsk, 630090, Russia
}

Received 30.03.2017, received in revised form 02.05.2017, accepted 16.05.2017

The article presents the factors dictating the further investigation of the algorithm for assessing the validity of criminal law. It is necessary to check the validity of criminal policy, criminal law drafts, to train students and legislators, to enhance the role of constitutional norms, the principles of criminal law in lawmaking and law enforcement activities; in order to interpret and apply the criminal law without excess controversy, improve it, prevent (eliminate) contradictions, fill gaps; for clarification, in-depth study of ambiguously interpreted, especially important issues of qualification of crimes (a kind of order for the science of criminal law).

A further development of the algorithm is also relevant because many of the proposed criteria require an in-depth, special interpretation in relation to the criminal legal sphere, different norms of the Criminal Code of the Russian Federation, and the specifics of criminal law. The study and generalization of the decisions of the ECtHR, the Constitutional Court of the Russian Federation should serve as a form of judicial supervision of the Plenum of the Supreme Court of the Russian Federation for the activities of the courts.

The study of 76 definitions of the Constitutional Court of the Russian Federation for 2016 showed that the most often complained criterion for the lawful restriction of human rights is certainty. Regarding the norms of criminal law, it is widely interpreted, includes all formal criteria for the lawful restriction of human rights, such as legality, accessibility, certainty, reasonable stability, predictability. The signs of a specific rule of criminal law are derived, according to the legal positions of the Constitutional Court of the Russian Federation, from the systemic interpretation of the norms of criminal law, i. e. not only from the objective and subjective elements of the offense described in a specific article of the Criminal Code of the Russian Federation, but also from the provisions of the General Part, other provisions of the Special Part of the Criminal Code of the Russian Federation, from their interpretation in generalizations (not equal to reviews) of judicial practice contained in decisions of the Plenum of the Supreme Court of the Russian Federation and decisions of the Presidium of the Supreme Court of the Russian Federation (the legal nature of the latter requires a separate study). Due to the systematic nature of the norms of criminal law, their interpretation changes in connection with the appearance of special rules in the Criminal Code of the Russian Federation, and any other changes in the criminal law.

(c) Siberian Federal University. All rights reserved

* Corresponding author E-mail address: criminal_law_nsu@mail.ru 
Well-known for a long time but not completely and clearly resolved issues are revealed. For example, these are the rules for the allocation and construction of special norms, the scope of the remaining part of the general norm when distinguishing special norms from it on different grounds (subject, method, object, etc.). The article grounds the conclusion that in the case of competition of general and special privileged norms providing for responsibility for the commission of a crime, criminal responsibility comes only in accordance with a special rule. In the absence of signs of a special norm raising the public danger of a crime, the general norm is likely to be applied.

Keywords: the value of the evaluation algorithm, the validity of the criminal law, the certainty of the means, criminal law, competition, the scope of the general rule, special norms, qualification rules.

DOI: 10.17516/1997-1370-0118.

Research area: law.

The peculiarity of the current condition of the Russian society and the state, according to S. Kapitsa, is that "in our era the historical time has shrunk to the limit ... Today history is under our eyes. People do not have time to adapt to it, while a new one is already coming. At such rates of development of both society and economy, internal equilibrium is lost...". Changing intra-state, intrasocial relations entail changes in relations between external and interstate relations.

The regulation of such complex changing, unstable social relations makes it necessary to correct the current legislation, including criminal law, even at a new level of development of science, law enforcement activity, deepening the theory of criminal law, for any "serious science is always on the verge of the unknown"2.

Scientists and law enforcement officials constantly state an insufficient justification for newly emerging laws. Decisions of the Constitutional Court of the Russian Federation, the amendments to the Criminal Code of the Russian Federation in July 2016, the Code of Administrative Offenses of the Russian Federation confirm this (after 6 months some of these innovations were changed again, I believe, not the last time ${ }^{3}$ ). In connection with this, the State Duma seriously considered raising the quality of bills. The speaker of the lower house Vyacheslav Volodin, having collected the leadership of eleven leading universities, asked them to help in the examination of the amendments being prepared and already introduced, including for the state order. Later, the expert association was joined by business associations and trade unions ${ }^{4}$.

In the federal state educational standard of higher education of the Russian Federation in 2016, one of the competencies of the bachelor's degree in jurisprudence was the development of legal norms; one of the types of professional activity is norm-setting activity, as a result, the graduate must be able to participate in the development of normative and legal acts 5 .

In the study of both general problems of criminalization (decriminalization) of acts, and with reference to specific crimes ${ }^{6}$; when qualifying crimes not fully enough, the constitutional norms, the criteria for the lawful restriction of human rights are not always taken into account. Meanwhile, the changes made in December 2016 in the Federal Constitutional Law On the Constitutional Court of the Russian Federation testify to a more stringent requirement to comply with formal and substantial (general and special) criteria for permitting the limitation of human rights by a legislator and a law enforcement official ${ }^{7}$.

Taking into account the decisions of the ECtHR presented in the international documents, including the European Convention on Human Rights, as well as the decisions of the Constitution 
of the Russian Federation, the decisions of the Constitutional Court, the doctrine of international and constitutional law, provisions of the Plenum of the Supreme Court of the Russian Federation on the supremacy of law, the legal category of restricting human rights and the criteria for their lawful restriction ${ }^{8}$, an approximate algorithm of verification of draft laws, current legislation and its application in terms of observing the conditions for the lawful restriction of fundamental human rights and freedoms is drawn up, which was discussed at the $14^{\text {th }}$ International Research-toScience conference Criminal Law: Development Strategy in the 21 $1^{\text {st }}$ Century on 26-27 January, 2017 in Moscow, Kutafin University (MSLA) ${ }^{9}$,

Even an approximate algorithm is necessary not only to check the validity of draft criminal law, to train students and legislators, but also to enhance the role of constitutional norms, the principles of criminal law in lawmaking and law enforcement activities; in particular, to verify the validity of the criminal policy; for the interpretation and application of criminal law; for clarification and in-depth study of ambiguously interpreted, especially important issues of qualification of crimes, the solution of which in theory and in practice sometimes occurs with violation of the conditions for the lawful restriction of human rights (a kind of order for the science of criminal law). Using the algorithm will allow solving problems of interpretation and application of the criminal law without much controversy, improving it, avoiding (eliminating) the contradiction, filling the gaps.

Further development of the algorithm is also relevant because many of the proposed criteria require a more in-depth, special interpretation with respect to the criminal law field, the different norms of the Criminal Code, the peculiarities of criminal law. Therefore, the task of further research is a more detailed, taking into account the specificity of the criminal law, in relation to different norms, interpretation of such conditions for the lawful restriction of human rights, the non-compliance of which is the reason why Russian citizens most often address to the Constitutional Court of the Russian Federation; for identification and solution of some problems of criminal law.

Based on the study of 76 definitions of the Constitutional Court of the Russian Federation passed in 2016, it can be concluded that most often Russian citizens apply to the Constitutional Court of the Russian Federation over the nonobservance, in their opinion, of the certainty criterion of the means of limiting human rights.

International law, the practice of the EU, the Constitutional Court of the Russian Federation, constitutionalists and theorists of law ${ }^{10}$ interpret the criterion of certainty in a broad sense - the law must be accessible, stable and predictable, and in the narrow sense it must be clear, unambiguous (in the algorithm, these are formal criteria for permitting the limitation of human rights ${ }^{11}$ ).

Based on the results of our research, the Constitutional Court of the Russian Federation initially discloses the criterion for the certainty of the norms providing for liability for crimes in the narrow sense, “... any crime, as well as punishment for its commission, must be clearly defined in the law, and so that proceeding directly from the text of the relevant standards - if necessary with the help of the interpretation given to it by the courts - one could foresee the penal consequences of his actions (inaction) of ... ", referring to the decrees earlier taken, namely No. 9-P taken on May 27, 2003, No. 8-P taken on May 27, 2008, No. 15-P taken on July 13, 2010, etc... ${ }^{12}$. Many definitions of the Constitutional Court state the mandatory establishment of both objective and subjective elements of an offense in qualifying crimes. It would seem that this is an axiom, but an analysis of published judicial practice, for example, in art. 286 of the Criminal Code of the Russian 
Federation on crimes against property (in the latter, in addition to the substantive content of the guilt, it is necessary to prove a selfish goal, defined in paragraph 28 of Resolution No. 51 of the Plenum of the Supreme Court of the Russian Federation of December 27, 2007 On Judicial Practice in Fraud, Misappropriation and Embezzlement ${ }^{13}$ in a different way than in many studies of this issue), the subjective side of the crime is often not proven.

Further, the Constitutional Court states that in fact the signs of the offense are derived not only from the text of the article of the Special Part of the Criminal Code of the Russian Federation, but also in connection with the provisions of the General Part of the Criminal Law, including the guiding principles and forms of guilt, the basis for criminal liability (Article 5, 8, 24 and 25) ${ }^{14}$.

In addition, the articles of the Special Part are interpreted in interrelation with each other ${ }^{15}$. And this is also an axiom. Service crimes, for example, are dispersed in three chapters of the Criminal Code: Sec. 23 (against the interests of the service in commercial and other organizations, Sec. 30 (against the interests of the public service in general) and Sec. 33 (against the interests of military service) of the Criminal Code of the Russian Federation. "The design of many crimes composed in sections 23 and 30 of the Criminal Code of the Russian Federation, and even many of their signs coincide. Moreover, many signs of the offenses contained in Section 23 of the Criminal Code of the Russian Federation are formulated by the method by contradiction. For example, the object of protection in it is the interests of such non-profit organizations that are not a state authority, local government and so on, that is, those non-profit organizations that are not listed in the rules of Sec. 30 of the Criminal Code of the Russian Federation." 16

In addition, in many crimes, there is a qualifying sign "using the official position", the uncertainty of which is most often (for crimes against property, for example, in 8 of 12 cases) addressed by convicted persons in the Constitutional Court. Naturally, for the interpretation of this aggravating circumstance, the Constitutional Court refers to the notes to Art. 201 and 285 of the Criminal Code, which call but do not reveal the signs of the subjects of these crimes.

According to the legal positions of the ECtHR and the legal literature ${ }^{17}$, the degree of specificity for the restriction of different rights may be different. For serious legal restrictions, for example, the deprivation of liberty, it is very important to strictly observe this requirement for the law so that the application of law is predictable. With respect to other rights, the requirement of clarity of law does not mean that all concepts contained in laws should be exhaustively disclosed in the text of the law itself.

The Russian Penal Code contains serious legal restrictions, including imprisonment. But due to its delicacy, the need to compare the criminal law norm with an indefinitely wide range of constantly changing circumstances, the legislator does not always manage to clearly formulate a ban. Such forced uncertainty, ambiguity should be compensated for, according to the legal positions of the ECtHR, for example, by the availability of explanations or the corresponding stable practice of the domestic courts on the application of this rule. I would stress a wellestablished case law, and not by the interpretation given to it by the courts, a separate court. Judicial precedent should be treated critically not only because Russia belongs to the continental law, where judicial precedents are not admitted to be its source, but also because at present they are often not flawless. In this regard, it is appropriate to mention the warning of the Chairman of the Constitutional Court of the Russian Federation V. Zorkin that 'any attempts to decisively inculcate 
Anglo-Saxon legal "shoots" to the Russian legal system are unjustified and destructive'. ${ }^{18}$

According to Article 126 of the Constitution of the Russian Federation, the Supreme Court is competent to identify established jurisprudence, give explanations on judicial practice and exercise judicial supervision over the activities of courts in the Russian Federation in its generalizations in the form of decisions of the Plenum. The legal literature provides strong evidence of the secondary normative nature of many of the regulations of the Plenum of the Supreme Court of the Russian Federation ${ }^{19}$. Recently, the explanations on the application of various norms of the criminal law (not in a specific criminal case) have been contained in the answers to questions submitted to the Supreme Court of the Russian Federation, and issued by the decision of the Presidium of the Supreme Court of the Russian Federation $^{20}$. Despite the fact that they are placed under the heading Reviews of Judicial Practice, they are closer in content to the generalization, although their legal nature requires independent research. Separate decisions of the Supreme Court of the Russian Federation are sometimes contradictory, they do not show the established judicial practice, and therefore do not eliminate the uncertainty of the norm.

It is therefore no accident that in the vast majority of the definitions of the Constitutional Court of the Russian Federation, when it is proved that there is no uncertainty in the interpretation of the applied means of restricting human rights, it refers to the decisions of the Plenum of the Supreme Court of the Russian Federation and in all (100 $\%$ ) definitions concerning the interpretation of the qualifying attribute "using official position". At the same time, the Constitutional Court of the Russian Federation indicates the interrelation of the norms contained in articles 159, 201, 285 of the Criminal Code of the Russian Federation; refers to the definition of the qualifying attribute "using official position", contained in the Resolution of the Plenum of the Supreme Court of the Russian Federation No. 51 On Judicial Practice in Cases of Fraud, Misappropriation and Embezzlement of December 27, 2007; reproduces the characteristics of an official and a person performing administrative functions in a commercial or other organization listed in the decisions of the Plenum of the Supreme Court of the Russian Federation on Corruption Crimes of 2009 and 2013.

And yet, despite the fact that the Constitutional Court of the Russian Federation has not found a violation of the criterion of the certainty of the means of restricting rights and refused to accept complaints of citizens, it is impossible not to admit that the problem of malfeasance has been discussed for centuries ${ }^{21}$, the repeated interpretation of signs of official crimes does not allow even specialists to justify and identify some of them. Thus, note 1 to art. 201 of the Criminal Code of the Russian Federation regards another organization but not a a commercial organization as a place of service, as well as a non-profit organization that is not a state body, a local government body, or a state or municipal institution. Civil legislation, other than commercial and non-commercial organizations, does not know other types of organizations. The Plenum of the Supreme Court of the Russian Federation does not explain what kind of organization it is. There is no convincing justification for the constantly changing place of service in the note to art. 285 of the Criminal Code of the Russian Federation, on which the dispersal of official crimes on the heads of the Criminal Code depends, and hence their public danger; for the allocation of the second type of organizational and administrative powers of officials in paragraph 4 of the decision of the Plenum of the Supreme Court of the Russian Federation, “... on the adoption of decisions that 
have legal significance and entail certain legal consequences (for example, the issuance of a temporary disability certificate by a medical worker, the establishment of a medical and social expertise of the fact of having a disability in a person by a medical institution worker, taking exams and giving grades by a member of the state examination (attestation) board)"22 (emphasis added by the author V. Plokhova). Obviously, these powers are not clear enough. In this regard, there is an incorrect application of explanations of the decisions of the Plenum of the Supreme Court of the Russian Federation by the courts. Thus, in the above paragraph 4 of the decision the Plenum of the Supreme Court of the Russian Federation, it is not about any teacher, but about a member of the examination board, while ordinary teachers are recognized as officials by some courts ${ }^{23}$. In the complaint against this verdict, not the certainty of the norm is disputed, but the principle "there is no crime without specifying it in the law" is violated, as one of the signs of an official crime that is an official is absent.

In addition, the definitions of the Constitutional Court of the Russian Federation set the direction for the formation of law enforcement practice $^{24}$. Therefore, the study and generalization of the decisions of the Constitutional Court of the Russian Federation should serve as a form of judicial supervision of the Supreme Court of the Russian Federation for the activities of the courts (Article 126 of the Constitution of the Russian Federation).

Without a systematic interpretation of the norms of criminal law, it is impossible, without violating the conditions for the lawful restriction of human rights, to apply general and special norms. The use of special frauds, for example, based on various signs, such as the sphere of social relations, the subject, the method; with the criminological amount of damage differing from the general norm, the conditions for bringing to criminal responsibility and release from it may lead to the violation of another already substantial principle and the criterion for the lawful restriction of human rights: there is not twice for the same thing. The study of the definitions of the Constitutional Court for 2016 in this aspect revealed the need to investigate in more detail the problem of the limits of confinement of offenses (deeds) in the remainder of the general rule (or the volume of the remaining part of the general rule). In the legal literature this issue is discussed with reference to a specific group of crimes $^{25}$, various options for its solution are shown, both in theory and in practice ${ }^{26}$. Thus, concerning the volume of art. 201 of the Criminal Code of the Russian Federation, some authors believe that since in Sec. 23 of the Criminal Code of the Russian Federation the abuse of office is not singled out as in Sec. 30 of the Criminal Code of the Russian Federation, criminal liability is not provided for their commission. Others argue that these actions are contained in the general rule. This position is correct provided that all the signs of a general norm are present in the deed. Indirectly, in the sense of the definition, abstracting from other nuances of the criminal case and the determination of the Constitutional Court ${ }^{27}$, it is reflected in the definition of the Constitutional Court of the Russian Federation of March 29, 2016, No. 638-O ${ }^{28}$.

The second aspect of this problem is also examined: if it is justified to include in the scope of the general rule the acts identified in separate articles of the Criminal Code of the Russian Federation (for example, Articles 139, 198, 199 of the Criminal Code of the Russian Federation), but not containing any indication of a special offenses, particularly, those taxes, fees, customs payments, which is specified in the special rate as criminological. In the legal literature, including the educational literature, some authors recognize "... the infliction of property damage as 
a result of evasion from payment of federal and local taxes or other mandatory payments by using fraudulently false documents (in the absence of signs of crimes provided for in Articles 194, 198 and 199 of the Criminal Code)..." 29 as one of the forms of committing a crime under Art. 165 of the Criminal Code of the Russian Federation, which can be regarded as the absence of criminality or the method of committing a crime. Others argue, "evasion of payment of taxes, fees and customs payments in the absence of a large amount necessary for tax crimes does not constitute an offense under Art. 165 of the Criminal Code of the Russian Federation. The norms on tax crimes are special in relation to the article of the Criminal Code of the Russian Federation. Having determined the line of the crime indicating the large size of evasion in these norms, the legislator thereby decriminalized tax evasion, which does not reach a large size." ${ }^{30}$

It seems that the origins of the first position are seen in the previous version of the criminal law. In connection with the appearance of a new wording or simply special rules in the Criminal Code, and any other changes in the Criminal Code of the Russian Federation, due to the systematic nature of criminal law, their interpretation varies.

The separation of these crimes from the general norms (Articles 201, 285 and 165 of the Criminal Code of the Russian Federation) is predetermined by the desire of the legislator to specify and narrow (in articles 198 and 199, only taxes and (or) fees, 2 ways of committing a crime are named: failure to submit returns or other documents ... or by including deliberately false information in them) a fairly common type of deviant activity and peculiarities of the regulatory legislation in this sphere (the reasonableness of such a decision is not investigated in this article). The current special norms, in comparison with the general ones (articles 165, 201, 285 of the Criminal Code) can be characterized as privileged (according to the notes contained in specific articles or in 23 and 30 sections of the Criminal Code). There is less criminality of the damage in the general norms (for example, in Article 165 of the Criminal Code of the Russian Federation it is more than 250 thousand rubles, whereas in Article 194 of the Criminal Code of the Russian Federation it is more than 2 million rubles, in Article 198 of the Criminal Code of the Russian Federation - more than 900 thousand rubles, in Article 199 of the Criminal Code of the Russian Federation - more than a million rubles). While sanctions in general norms are greater than in special ones, special conditions for exemption from criminal liability are not provided for them. With competition of the general and special norms in such a situation, criminal liability only comes in accordance with a special rule. And all evasion from payment of customs duties, taxes, fees in the absence of any indication of a crime, provided for by Art. 194, 198 and 199 of the Criminal Code (size or method) are not criminally punishable. Otherwise, the principle of certainty and proportionality of a crime to established sanctions is violated.

Such a concept is set out by the Supreme Court in the decision of the Presidium of September 28, 2016 with reference to the norms of the Criminal Code of the Russian Federation, changed in July 2015. The response to question 1.4 that is if the sentences against persons convicted under Art. 159 and 159.4 (in the version of the Federal Law of November 29, 2012 No. 207-FZ) for the theft of someone else's property by fraud subject entered into legal force are subject to review and adjustment in accordance with the new criminal law on the basis of Art. 10 of the Criminal Code of the Russian Federation, the answer is subject in case if a person is convicted under Article 159.4 of the Criminal Code of the Russian Federation (as amended by Federal Law No. 207 FZ of November 29, 2012) or any part of Art. 159 of 
the Criminal Code for fraud, involving deliberate non-fulfillment of contractual obligations in the field of entrepreneurial activities, when the parties to the contract are only individual entrepreneurs (or commercial organizations) and the cost of the stolen another's is less than 10 thousand rubles. In regard with footnote 1 to article 159 of the Criminal Code of the Russian Federation, such a person is subject to exemption from punishment in the new wording because of the elimination of the crime of the act containing these characteristics ${ }^{31}$.

It is no accident, apparently, that paragraph 16 of resolution No. 51 of the Plenum of the Supreme Court of the Russian Federation of December 27, 2007 On Judicial Practice in Cases of Fraud, Misappropriation and Embezzlement, notes, "Deception or abuse of trust for the purpose of obtaining illegal property benefits can be expressed, for example, by providing forged documents exempting payment of prescribed fees by a person (other than those specified in Articles 194, 198, 199 of the Criminal Code of the Russian Federation)... "32 (emphasis added by the author V. Plokhova).

Theorists and law enforcers are guided by approximately such considerations releasing a mother under the age of 16 years who killed a newborn child from criminal liability. The legislator could not establish the responsibility for the 15 -year-old mother of a newborn child to be twice as large as for the 16-year-old mother (see the sanctions in point 2 of Article 105 and Article 106 of the Criminal Code of the Russian Federation). In order to substantiate the correctness of such a solution to the issue, it seems appropriate to bring the opinion of the Commission that acted earlier in the system of the European Convention, that "... among other things, the use of criminal law is prohibited ... with respect to those facts that can not be reasonably included in the text of the law..." ${ }^{33}$.

In another way, apparently, it is necessary to argue in the event of the allocation of an aggravated special rule. In the absence of those features for which a special rule is singled out, general application is to be applied.

The foregoing testifies to the need for further investigation of the problems identified in relation to the various norms of the Criminal Code of the Russian Federation, on the basis of which it is important to formulate and propose the rules for the allocation of special norms from the general ones for different situations to the legislator and for fixing their signs in articles of the Criminal Code, and the rules for the qualification of crimes to the law enforcement officer.

Quoted after the article This Incredible Kapitsa by Iu. Medvedev, in Rossiiskaia Gazeta, 2012, August 15.

Ibid.

See FZ No. 8-Ф3 of 07.02.2017, in Rossiyskaya Gazeta. 2017, February 10.

See Rossiiskaia Gazeta. 2016, December 6; Rossiiskaia Gazeta. 2017, March 13.

See FSES of HE in the field of training Law major No. 40.03.01 (bachelor's level). Approved by the order of the Ministry of Education and Science of the Russian Federation dated 01.12.2016 No. 1511. Available at: www.osu.ru/docs/fgos/vo/ bak 40.03.01.pdf

6 See one of the latest studies of this problem: Avdalian M.E. (2015). The grounds for criminalization and criminological signs of violation of traffic rules and the operation of vehicles. Moscow, 14-53. Available at: ww.twirpx.com/file/1841608/ This FKZ emphasizes that the interpretation of the norm of the Constitutional Court is mandatory, it is indicated who is responsible for eliminating the gaps and in what terms; it reminds about the use of the mechanism of responsibility for non-compliance with the requirements of the FKZ. See On Amending the Federal Constitutional Law On the Constitutional Court of the Russian Federation: Federal Constitutional Law No. 11-FKZ of December 28, 2016, In Rossiiskaia Gazeta. 2017, February 9.

8 See Plokhova, V.I. (2015). Substantiation of tort legislation by the requirements of the Constitution of the Russian Federation, In Journal of the Siberian Federal University, Humanities, 8 (3), 527-532; Plokhova, V.I. (2014). Conditions for the lawful restriction of human rights and freedoms in the criminal sphere, In Criminological Journal of Baikal State University of Economics and Law, 4, 83-92; Plokhova, V.I. (2016). Substantial conditions for the lawful restriction of human rights and freedoms in the criminal sphere (general issues), In Criminological Journal of Baikal State University of Economics and Law, 10 (1), 105-116. 
$9 \quad$ Plokhova, V.I. (2017). Algorithm for assessing the compliance of laws and law enforcement activities with the conditions for the lawful restriction of human rights in the criminal-legal sphere. Criminal law: development strategy in the 21st century: materials of the 14th International Research-to-Practice Conference (January 26-27, 2017). Moscow, the original layout, 136-139.

10 The analysis of the legal literature, international treaties and decisions of the ECtHR on this issue is shown in the works: Oganesian, V.A. (2011). Principles of criminal justice in international law. Evolution and features of implementation. Moscow, NOTA BENE, 161-165, 197-202, and others; Plokhova, V.I. (2014). Conditions for the lawful restriction of human rights and freedoms in the criminal sphere, In Criminological Journal of Baikal State University of Economics and Law, 4, 83-92.

11 Plokhova, V.I. (2017). Algorithm for assessing the compliance of laws and law enforcement activities with the conditions for the lawful restriction of human rights in the criminal-legal sphere. Criminal law: development strategy in the 21st century: materials of the 14th International Research-to-Practice Conference (January 26-27, 2017). Moscow, the original layout, $137-138$.

12 See, for example, Definition of the Constitutional Court of the Russian Federation of May 26, 2016 On the Refusal to Accept the Complaint of Citizen Vitaliy Radchenko for Violating His Constitutional Rights by Part Three of Article 159, a Note to Article 201 and Paragraph 1 of the Notes to Article 285 of the Criminal Code of the Russian Federation, 2. Available at: www.ksrf.ru/RU/DECISION/Pages/default.aspx

13 Available at: www.supcourt.ru/Show_pdf.php?Id=7252

14 Ibid, 3.

15 See in more detail: Plokhova, V.I. (2011). System interpretation of the norms of the Special Part of the Criminal Law. Moscow, Iurlitinform, 215-282; Plokhova, V.I. (2013). Evasion from military or alternative civilian service. Barnaul, Publishing House of Altai University, 104.

16 Plokhova, V.I. System interpretation of the norms of the Special Part of the Criminal Law. Moscow, Iurlitinform, 215-282.

17 See Lipkina, N.N. (2010). The principle of freedom of discretion of states: the legal positions of the European Court of Human Rights, In Lipkina N.N under the ed. of Tiunov O.I., Saratov, Publishing House of Saratov State Academy of Law, 172 p.; Lipkina, N.N. (2008). The legal position of the European Court of Human Rights regarding the freedom of discretion of states in intervening in rights and fundamental freedoms. Thesis of $\mathrm{PhD}$ in. Law. Moscow, 225 p.; Plokhova, V.I. (2014). Conditions for the lawful restriction of human rights and freedoms in the criminal sphere, In Criminological Journal of Baikal State University of Economics and Law, 4, 85; Plokhova, V.I. (2016). Substantial conditions for the lawful restriction of human rights and freedoms in the criminal sphere (general issues), In Criminological Journal of Baikal State University of Economics and Law, 10 (1), 105-116.

18 Zor'kin, V. Economy and law: a new context, In Rossiiskaia gazeta, 2014, May 22.

19 See Obrazhiev, K.V. (2015). The system of formal (legal) sources of Russian criminal law. Moscow, Iurlitinform. 253-281.

20 See, for example, the answers to questions from courts on the application of Federal Law No. 323-FZ-N 326-FZ of July 3, 2016, aimed at improving criminal liability for corruption crimes and economic crimes, as well as grounds and order of exemption from criminal liability (entered into force on July 15, 2016): Approved by the Presidium of the Supreme Court of the Russian Federation on September 28, 2016. Available at: www.supcourt.ru/Show_pdf.php?Id=11051

21 For an overview of the problems, see Kozlov A.P. (2014). Service crimes. Krasnoyarsk, SibIuI Federal Drug Control Service of Russia, $734 \mathrm{p}$.

22 On judicial practice in cases of abuse of official authority and exceeding official authority: Decree of the Plenum of the Supreme Court of the Russian Federation, No. 19 of October 16, 2009. Available at: www.supcourt.ru/Show_pdf. php?Id=6439

23 On the refusal to accept the complaint of citizen Sadykov Rauf Gaisinovich for violation of his constitutional rights by paragraphs 1 and 4 of the note to Article 285 and part 1 of Art. 290 of the Criminal Code of the Russian Federation: the definition of the Constitutional Court of the Russian Federation No. 1816-O of November 21, 2013. Available at: www. supcourt.ru/Show_pdf.php?Id=6439

24 See Plaksina, T.A. (2017). The practice of judicial constitutional review on certain issues regulated by the Federal Law On Counteracting Extremist Activity, In Altai Law Bulletin, 1 (17), 42-49.

25 See Losev, V.V. (2015). Abuse of official powers as a basic (generic) concept of deliberate crime of officials, In Problems of Strengthening Law and Order: Science, Practice, Trends: Collection of Scientific Articles ed. by V.M. Khomich [and others]; Research-to-Practice Center for Strengthening the Rule of Law and Order of the Prosecutor General's Office of the Republic of Belarus. Minsk, BSUFK, 8, 100-108.

26 See Kuznetsova, A.V. (2012). Special types of crimes against the interests of service in commercial or other organizations, In Legality, 2, 44-46; Rogova, N.N. (2014). Features in the qualification of crimes in the competition of criminal law norms, In Russian investigator, 23. Plokhova, V.I. Systemic interpretation of the norms of the Special Part of Criminal Law. 257.

27 The criterion of definiteness of blanket norms, observance of material criteria for the admissibility of human rights restrictions is the topic of the next study.

28 On the refusal to accept the complaint of citizen Novomlinov Sergey Vasilyevich for violation of his constitutional rights by part 1 of article 201 of the Criminal Code of the Russian Federation: the definition of the Constitutional Court of the Russian Federation No. 638-O of March 29, 2016. Available at: www.supcourt.ru/Show_pdf. Php? Id = 6439.

29 The Criminal Law of Russia. (2012). Special part: textbook (ed. by F.R Sundundov, M.V. Talan). Moscow, Statut, 142. Available at: evcppk.ru/problemy-kvalifikacii-prestuplenij/1260-kvalifikaciya-dlyashhixsya-i-prodolzhaemyx-prestuplenij.htm. The document is provided by ConsultantPlus at: www.consultant.ru Analysis of literature and practice under Art. 165 of the Criminal Code is proposed in the works: Babushkina, E.A. (2012). Criminal responsibility for causing property damage by deception and abuse of trust in the absence of signs of theft, In 
Bulletin of Tomsk State University, 356, 113-116; Plokhova, V.I. (2006). A special part of criminal law. Part 1. Barnaul, Publishing House of Altai University, 192-197.

30 Commentary on the Criminal Code of the Russian Federation in 2 vol. (2015). Vol. 1, $2^{\text {nd }}$ edition. Ed. by A.V. Brilliantova. Moscow, Prospect, 411.

31 Available at: www.supcourt.ru/Show_pdf.php?Id=6439 In connection with this explanation, the question of the validity of the formulation of petty theft (Article 7.27 of the Code of Administrative Offenses of the Russian Federation) again involuntarily arises: it is possible under other conditions (the stolen amount is not more than 2500 roubles, non-violent and unconcealed form of embezzlement, in the absence of qualifying signs of embezzlement: by a group of persons by prior conspiracy, by an organized group, with illegal entry into the premises or other storage, housing, from a bag ..., an oil pipeline .., using one's official position; Fraud is punishable with 10,000 rubles, and in small commercial bribery, their size should not exceed 10,000 rubles, qualifying signs that are not taken into accountare a group of persons by prior agreement, an organized group, for knowingly or simply illegal actions involving extortion of the subject of bribery, by a person holding high public office.

32 Available at: www.supcourt.ru/Show_pdf.php?Id=6439

33 Oganesian, V.A. (2011). Principles of criminal justice in international law. Evolution and features of implementation. Moscow, NOTA BENE, 199.

\title{
Использование решений Европейского Суда
} по правам человека, Конституционного Суда Российской Федерации
при исследовании проблем уголовного права РФ
(статья первая)

\author{
В.И. Плохова \\ Новосибирский государственный университет \\ Россия, 630090, Новосибирск, ул. Пирогова, 2
}

$\overline{\text { Приводятся факторы, диктующие дальнейтее исследование алгоритма оиенки обоснован- }}$ ности уголовного закона. Он необходим для проверки обоснованности уголовной политики, проектов уголовного закона; для обучения студентов и законодателей; для повышения роли конституционных норм, принцииов уголовного права в законотворческой и правоприменительной деятельности; для того, чтобы без лишней полемики толковать и применять уголовный закон, совершенствовать его, не допускать (устранять) противоречия, восполнять пробель; для уточнения, углубленного изучения неоднозначно толкуемых, особо важных вопросов квалификации преступлений (своего рода заказ науке уголовного права).

Дальнейтая разработка алгоритма актуальна и потому, что многие из предложенных критериев требуют углубленного, особого толкования применительно к уголовно правовой сфере, разным нормам УК РФ, особенностям уголовного права. Изучение и обобщение решений ЕСПЧ, Конституционного Суда РФ должно служить формой судебного надзора ВС РФ за деятельностью судов

Изучение 76 определений Конституиионного Суда РФ за 2016 г. показало, что наиболее часто обжалуемым критерием правомерного ограничения прав человека является определенность. В отношении норм уголовного права она трактуется широко, включает все формальные критерии правомерного ограничения прав человека: законность, доступность, определенность, разумная стабильность, предсказуемость. Признаки конкретной нормы уголовного права выводятся по правовым позициям КС РФ из системного толкования норм уголовного права, $m$. е. не только из объективных и субъективных признаков состава преступления, описанного в конкретной статье УК РФ, но и из положений Общей части, других норм Особенной части УК РФ, из толкования их в обобщениях (не равно обзорах) судебной практики, содержащихся в 
постановлениях Пленума Верховного Суда РФ и постановлениях Президиума Верховного Суда РФ (правовая природа последних требует отдельного исследования). Из-за системности норм уголовного права толкование их меняется в связи с появлением специильных норм в УК РФ и любых других изменений уголовного закона.

Обнажены давно известные, но не до конца и нечетко разрешенные вопросы. Например, правила выделения и конструирования специальных норм, объем оставшейся части общей нормы при выделении из нее специиальных норм по разным признакам (субъекту, способу, предмету и др.). Обоснованы выводы: при конкуренции общей и специильньх привилегированных норм, предусматривающих ответственность за совершение преступления, уголовная ответственность наступает только по специильной норме; при отсутствии повышающих общественную опасность преступления признаков специиальной нормы, видимо, подлежит применению общзая.

Ключевые слова: значение алгоритма оценки, обоснованность уголовного закона, определенность средства, уголовное право, конкуренция, объем общей нормы, специиальные нормы, правила квалификации.

Научная специиальность: 12.00.00 - юридические науки. 